\title{
Impact of variety on resistance to cold stress at physiological levels in Linum usitatissimum
}

\author{
Maryam Ghoreishi ${ }^{1}$, Fatemeh Rahmani** ${ }^{1}$, Babak Abdollahi Mandoulakani ${ }^{2}$, Abdollah Hassanzadeh \\ Gorttapeh $^{3}$
}

\author{
${ }^{1}$ Biology Department, Faculty of Sciences, Urmia University, Urmia, Iran \\ ${ }^{2}$ Department of Plant Breeding and Biotechnology, Urmia University, Urmia, Iran \\ ${ }^{3}$ Agricultural and Natural Resources Research Center of West Azerbaijan, Urmia, Iran
}

\section{*Corresponding author: f.rahmani@urmia.ac.ir}

\begin{abstract}
In this study, thirty Linum usitatissimum varieties were classified based on pigments, malondialdehyde, betaine and proline contents as well as antioxidant enzymes activity under cold stress. Based on the UPGMA clustering, varieties were divided into three clusters. Cluster I comprised of 13 varieties with low cold tolerance. Cluster II contained 5 varieties with moderate cold tolerance and cluster III manifested of 12 varieties with high cold tolerance. Our analyses based on multiple physiological indexes, revealed cold hardiness difference among Linum usitatissimum varieties which could provide good reference for commercial flax production. The TN-97-55, TN97-92, TN-97-290 and TN-97-291 were identified as tolerant varieties and recommended for cultivation in cold areas.
\end{abstract}

Keywords: Cold stress, Betaine, Flax (Linum usitatissimum L.), Pigment content, Proline, MDA, CAT, POX.

Abbreviations: Chl_Chlorophyll; MDA_Malondealdehyde; CAT_Catalase; POX_Peroxidase; ROS_Reactive oxygen species; TCA_ Trichloroacetic acid; UPGMA_Unweighted Pair Group Method with Arithmetic Mean.

\section{Introduction}

Low temperature is one of the most important factors limiting productivity and distribution of plants. In exposing of plant to low temperature, visible symptoms appear including wilting, chlorosis, or necrosis (Ruelland and Zachowski 2010). Low temperature causes changes in cell membrane structure and lipid composition (Matteucci et al., 2011), cellular leakage of electrolytes and amino acids, diversion of electron flow to alternate pathways (Seo et al., 2010), membrane depolarization, increase in cytoplasmic calcium, and transcription of cold- and touch-responsive genes (Braam 2005), changes in protein content and enzyme activities (Ruelland and Zachowski 2010), alteration in plastids, thylakoid membranes, phosphorylation of thylakoid proteins and mitochondria (Zhang et al., 2011). At the physiological level, photosynthesis is strongly affected by exposure to cold. Cold stress reduces the capacity for energy utilization leading to photosynthesis inhibition (Ruelland and Zachowski 2010). The Low temperature at seedling and reproductive stages is the major problem, resulting in slow establishment and low seed set. Plants differ in their resistance to chilling $\left(0-15^{\circ} \mathrm{C}\right)$ and freezing $\left(<0{ }^{\circ} \mathrm{C}\right)$ temperatures. The exposing of plants to chilling or non-freezing temperatures will change biochemical and physiological activities in association with alteration in gene expression, bio-membrane lipid composition, and small molecule accumulation. In general, plants from temperate climatic regions are considered as chilling tolerant (Sanghera et al., 2011). Chilling sensitive varieties are typically tropical genotypes. Crop genotypes / lines with better survival or performance to low temperature are known as cold tolerant. Cold tolerance includes increased chlorophyll accumulation, reduced sensitivity of photosynthesis, improved germination, pollen fertility and seed set (Sanghera et al., 2011). In cold stress-tolerant plants, many genes involved in the synthesis of osmo-protectants and organic compounds such as amino acids (e.g proline), amines (e.g glycinebetaine and polyamines) and a variety of sugars and sugar alcohols (e.g mannitol, trehalose and galactinol) are accumulated (Sanghera et al., 2011). Flax (Linum usitatissimum L.), is widely cultivated for its application in textile, food, chemical and pharmaceutical industries. However, biotic and abiotic stresses negatively influence flax production (Alexey et al., 2016). Patel and Franklin 2009 indicated that the prolonged cold temperature causes growth retardation, late flowering, elongation of stems and an increase in total dry weight in flax. One of the major challenges in plant physiological studies is to increase the plant productivity under adverse environmental conditions. This research was conducted to investigate the relationship between cold stress and physiological properties in thirty different flaxseed varieties for evaluation of their cold-resistance breeding potential and ultimately cultivation in commercial production.

\section{Results}

Influence of low temperature photosynthetic pigments and MDA contents

Varieties including TN-97-18 (19.06 $\left.\mathrm{mgg}^{-1} \mathrm{FW}\right)$, TN-97-94 (18.89 $\left.\mathrm{mgg}^{-1} \mathrm{FW}\right)$, TN-97-92 (18.87 $\left.\mathrm{mgg}^{-1} \mathrm{FW}\right)$, TN-97-26 
(18.66 $\left.\mathrm{mgg}^{-1} \mathrm{FW}\right)$ and TN-97-290 (18.49 $\left.\mathrm{mgg}^{-1} \mathrm{FW}\right)$ displayed the highest accumulation of Chlorophyll a than the other varieties. The lowest Chlorophyll a content was detected in TN97-2 (2.23 $\left.\mathrm{mgg}^{-1} \mathrm{FW}\right)$, TN-97-1(2.18 $\left.\mathrm{mgg}^{-1} \mathrm{FW}\right)$ and TN-97178 (2.13 $\left.\mathrm{mgg}^{-1} \mathrm{FW}\right)$ varieties (Fig. 1A).

The TN-97-92 (11.24 mgg $\left.{ }^{-1} \mathrm{FW}\right)$, TN-97-94 (11.01 $\mathrm{mgg}^{-1}$ FW) and TN-97-290 (10.77 $\left.\mathrm{mgg}^{-1} \mathrm{FW}\right)$ showed the highest chlorophyll b content while the lowest was obtained in the leaves of TN-97-6 (2.37 $\mathrm{mgg}^{-1} \mathrm{FW}$.) and TN-97-178 (2.31 mgg${ }^{1} \mathrm{FW}$ ) varieties (Fig. 1B).

The highest content of total chlorophyll belonged to TN-9718 (19.06 $\left.\mathrm{mgg}^{-1} \mathrm{FW}\right)$, TN-97-94 (18.89 $\left.\mathrm{mg} \mathrm{g}^{-1} \mathrm{FW}\right)$ and TN-97$92\left(18.8 \mathrm{mgg}^{-1} \mathrm{FW}\right)$ while the lowest content appeared in the leaves of TN-97-178 (3.78 $\mathrm{mgg}^{-1} \mathrm{FW}$.), TN-97-6 (4.67 $\mathrm{mg} \mathrm{g}^{-1}$ FW) and TN-97-2 (4.7 $\mathrm{mgg}^{-1} \mathrm{FW}$ varieties (Fig. 1C).

The highest carotenoid content belonged to TN-97-18 (2.3 mgg $\left.{ }^{1} \mathrm{FW}\right)$ and TN-97-92 (2.15 $\left.\mathrm{mgg}^{-1} \mathrm{FW}\right)$ while TN-97-2 (0.48 $\left.\mathrm{mgg}^{-1} \mathrm{FW}\right), \mathrm{TN}-97-178\left(0.42 \mathrm{mgg}^{-1} \mathrm{FW}\right)$ and TN-97-1 (0.41 $\mathrm{mgg}^{-1} \mathrm{FW}$ ) varieties displayed the lowest content (Fig. 3D).

Different flaxseed varieties differed in MDA content of their leaves. The TN-97-92 (0.15 $\left.\mu \mathrm{mol} \mathrm{g}^{-1} \mathrm{FW}\right)$ and TN-97-55 (0.234 $\left.\mu \mathrm{mol} \mathrm{g}{ }^{-1} \mathrm{FW}\right)$ contained the highest level and TN-97-209 $\left(0.016 \mu \mathrm{mol} \mathrm{g}{ }^{-1} \mathrm{FW}\right)$ and TN-97-6 (0.015 $\left.\mu \mathrm{mol} \mathrm{g}{ }^{-1} \mathrm{FW}\right)$ showed the lowest accumulation of that (Fig. 2).

\section{Influence of low temperature on CAT and POX enzymatic activities in Flaxseed}

Under our cold stress conditions, the highest CAT activity was detected in TN-97-290, TN-97-55 and TN-97-92 with 1.12, 1.16 and $1.20 \mu \mathrm{M} \mathrm{H}_{2} \mathrm{O}_{2} \mathrm{~min}^{-1} \mathrm{mg}^{-1}$ protein while TN-97-26 and TN-97-6 displayed the lowest activities of 0.47 and $0.52(\mu \mathrm{M}$ $\mathrm{H}_{2} \mathrm{O}_{2} \mathrm{~min}^{-1} \mathrm{mg}^{-1}$ protein), respectively (Fig. 3A).

In case of POX enzymatic activity, TN-97-94 and TN-97-290 $\left(0.07 \mu \mathrm{M} \mathrm{H}_{2} \mathrm{O}_{2} \mathrm{~min}^{-1} \mathrm{mg}^{-1}\right.$ protein) showed the highest whereas the lowest activity was obtained for TN-97-6 $\left(0.006 \mu \mathrm{M} \mathrm{H}_{2} \mathrm{O}_{2}\right.$ $\mathrm{min}^{-1} \mathrm{mg}^{-1}$ protein) and TN-97-2 (0.01 $\mu \mathrm{M} \mathrm{H}_{2} \mathrm{O}_{2} \mathrm{~min}^{-1} \mathrm{mg}^{-1}$ protein) varieties. Based on correlation analysis, a significant positive relation was observed between POX and CAT activities ( $\mathrm{r}=0.574)$ (Table 2) (Fig. 3B).

Based on the results of variance analysis, significant differences $(\mathrm{P} \leq 0.01)$ observed among flax varieties for all studied traits under cold conditions (Table 3 ). The significant interaction effect showed that chilling stress has caused different reactions among the varieties supporting the existence of enough diversity. This variation reflects different potential of cold adaptability in flaxseed plants.

\section{Influence of low temperature on betaine and proline contents}

The extent of betaine content was markedly differed among flax varieties under low temperature stress (Fig. 4A). The flaxseed varieties including TN-97-290 (1.62 $\left.\mu \mathrm{g} \mathrm{g}^{-1} \mathrm{DW}\right)$ and TN-97-55 (1.58 $\left.\mu \mathrm{g} \mathrm{g}^{-1} \mathrm{DW}\right)$ appeared with highest accumulation of betaine in their leaves. The lowest betaine contents were obtained in the leaves of TN-97-2 (0.26 $\left.\mu \mathrm{g} \mathrm{g}^{-1} \mathrm{DW}\right)$ and TN-97$6\left(0.35 \mu \mathrm{g} \mathrm{g}^{-1} \mathrm{DW}\right)$ varieties.

The flax varieties including TN-97-92 (1.56 $\left.\mu \mathrm{g} \mathrm{g}^{-1} \mathrm{FW}\right)$ and TN-97-290 (1.46 $\mu \mathrm{g} \quad \mathrm{g}^{-1}$ FW) demonstrated the highest accumulation of proline (Fig. 4B). The minimum proline content was detected in the leaves of TN-97-2 $\left(0.40 \mu \mathrm{g} \mathrm{g}^{-1} \mathrm{FW}\right)$ and TN-97-33 (0.38 $\left.\mu \mathrm{g} \mathrm{g}^{-1} \mathrm{FW}\right)$ varieties. Positive and significant correlation was obtained between betaine and proline contents ( $\mathrm{r}=0.658)$ (Table 2).

\section{Clustering and principal component analysis}

Cluster analysis using UPGMA algorithm could clearly classify varieties into three groups (Fig.5). Cluster I comprised of TN97-1, TN-97-93, TN-97-12, TN-97-14, TN-97-91, TN-97-90, TN-97-273, TN-97-249, TN-97-209, TN-97-210, TN-97-2, TN97-6 and TN-97-178. The TN-97-28, TN-97-33, TN-97-177, TN-97-301 and TN-97-167 constructed cluster II. Cluster III manifested of TN-97-18, TN-97-94, TN-97-26, TN-97-95, TN97-27, TN-97-274, TN-97-106, TN-97-92, TN-97-290, TN-9755, TN-97-289 and TN-97-291. Correlation coefficient of dissimilarity matrix and dendrogram was calculated 0.94 .

Table 4 presents the principal component and percentage contribution of each component to the total variation. The first principal component (PC1) accounted for $58.6 \%$ of the total variation. All parameters contributed negatively to the first component (Table 4). Second principal component (PC2) describes $25.3 \%$ of the total variation with contribution of total chlorophyll (0.306), chlorophyll a (0.304), chlorophyll b (0.304) and carotenoid (0.276). The third principal component accounted for $6.1 \%$ of the total variation. POX and carotenoid contributed as the highest (0.286) and the lowest (0.001), respectively. POX (0.682) contributed more to the variation in principal component 4 while CAT (0.269) and MDA (0.068) contributed less to the variation. Cumulatively, these 4 principal components showed $94 \%$ of the total variation. The PC1 showed all nine parameters had negative loading on the first component. In PC2, chlorophyll a, chlorophyll b, total chlorophyll and carotenoid showed positive loading to the second component.

\section{Discussion}

Each plant species has its unique set of temperature requirements which are optimum for proper growth and development. Low temperature is one of the abiotic stresses and principal cause of crop failure worldwide which has been studied for long time in many economically important crops (Farooq et al., 2009). Photosynthetic pigments content is an indirect index reflecting plant photosynthetic ability, and chloroplast is a strong cold sensitive organ in plant. Low temperature stress causes increase in permeability of cell membranes, inhibiting chlorophyll synthesis process and destructing chloroplast structure. The long duration of low temperature will also accelerate chlorophyll decomposition which consequently reduce the chlorophyll content (Wang and Guo 2005). The chlorophyll stability is an effective index appraising cold resistance of crops (Zhang et al., 2015). In this study, we examined chlorophyll content under low temperatures of $8 / 11{ }^{\circ} \mathrm{C}$. According to our data analysis, TN-97-55, TN-9792, TN-97-290 and TN-97-291 were classified as cold tolerant varieties having the maximum level while TN-97-2, TN-97-6, TN-97-14 and TN-97-301 with the lowest content were identified as sensitive varieties. Aghaee et al. (2011) reported reduction in total chlorophyll concentration in rice leaves under cold stress. Moreover, Habibi et al. (2011) observed that the low temperature significantly decreased the chlorophyll $\mathrm{a}$ and $\mathrm{b}$ contents of leaves. 
Table 1. Name and origin of the studied flaxseed varieties.

\begin{tabular}{lccc}
\hline Variety & Origin & Variety & Origin \\
\hline TN-97-1 & Khalkhal & TN-97-94 & Miandoab \\
TN-97-2 & Kerman & TN-97-95 & Kerman \\
TN-97-6 & Kerman & TN-97-106 & Ardabil \\
TN-97-12 & Chaharmahalebakhtiari & TN-97-167 & Baft \\
TN-97-14 & Markazi & TN-97-177 & Bardsir \\
TN-97-18 & Khozestan & TN-97-178 & Bardsir \\
TN-97-26 & Khozestan & TN-97-209 & Osko \\
TN-97-27 & Kerman & TN-97-210 & Sarab \\
TN-97-28 & Zabol & TN-97-249 & Esfahan \\
TN-97-33 & Bonab & TN-97-273 & Shahindezh \\
TN-97-55 & Shahindezh & TN-97-274 & Ardabil \\
TN-97-90 & Shahindezh & TN-97-289 & Khalkhal \\
TN-97-91 & Shahindezh & TN-97-290 & Ardabil \\
TN-97-92 & Tekab & TN-97-301 & Shahindezh \\
TN-97-93 & Miandoab & & Shazand \\
\hline
\end{tabular}
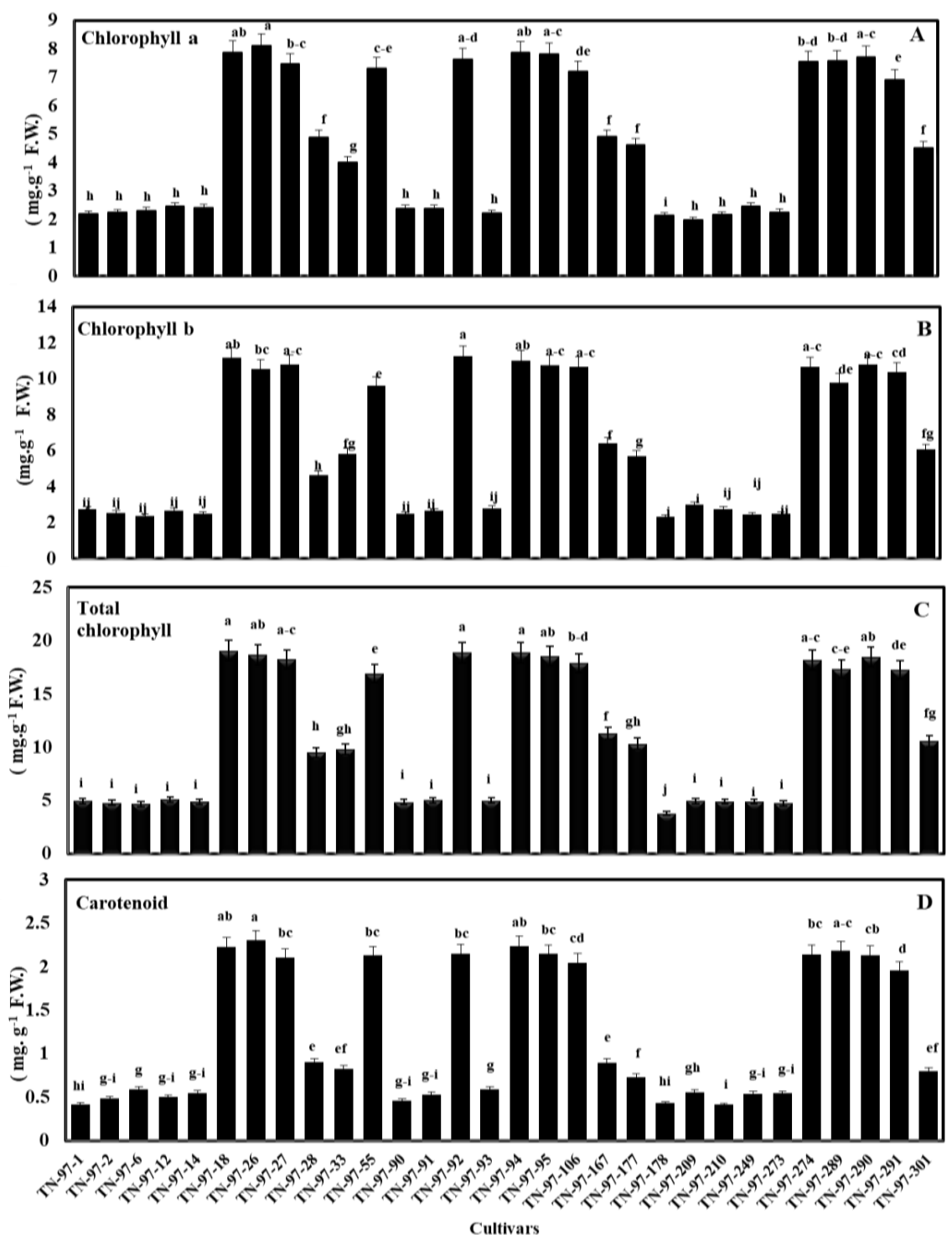

Fig 1. Changes of chlorophyll a (A), chlorophyll b (B), total chlorophyll (C) and carotenoid (D) contents in leaf of different flaxseed varieties grown for 30 days under cold stress with $13 \mathrm{~h} /$ day at $11^{\circ} \mathrm{C}$ and $11 \mathrm{~h} /$ night at $8{ }^{\circ} \mathrm{C}$. 
Table 2. Correlation analyses among cold resistance indices in different flaxseed varieties.

\begin{tabular}{|c|c|c|c|c|c|c|c|c|c|}
\hline & Chl a & Chl b & $\mathrm{T}$ chl & Car & MDA & CAT & POX & Betaine & Proline \\
\hline Chl a & 1 & & & & & & & & \\
\hline $\mathrm{Chl} \mathrm{b}$ & $0.984^{* *}$ & 1 & & & & & & & \\
\hline $\mathrm{T}$ chl & $0.994^{* *}$ & $0.997^{* *}$ & 1 & & & & & & \\
\hline $\mathrm{Car}$ & $0.971^{* *}$ & $0.975^{* *}$ & $0.977^{* *}$ & 1 & & & & & \\
\hline MDA & $0.337^{* *}$ & $0.319^{* *}$ & $0.327^{* *}$ & $0.358^{* *}$ & 1 & & & & \\
\hline CAT & $0.218^{*}$ & $0.245^{*}$ & $0.235^{*}$ & $0.263^{*}$ & $0.516^{* *}$ & 1 & & & \\
\hline POX & $0.561^{* *}$ & $0.550^{* * *}$ & $0.556^{* *}$ & $0.579^{* * *}$ & $0.443^{* *}$ & $0.574^{* *}$ & 1 & & \\
\hline Betaine & $0.211^{*}$ & $0.217^{*}$ & $0.215^{*}$ & $0.257^{*}$ & $0.482^{* *}$ & $0.477^{* *}$ & $0.655^{* * *}$ & 1 & \\
\hline Proline & $0.246^{*}$ & $0.245^{*}$ & $0.247^{*}$ & $0.276^{* *}$ & $0.530^{* * *}$ & $0.498^{* *}$ & $0.611^{* *}$ & $0.658^{* *}$ & 1 \\
\hline
\end{tabular}

**. Correlation is significant at the 0.01 level (2-tailed).

*. Correlation is significant at the 0.05 level (2-tailed).

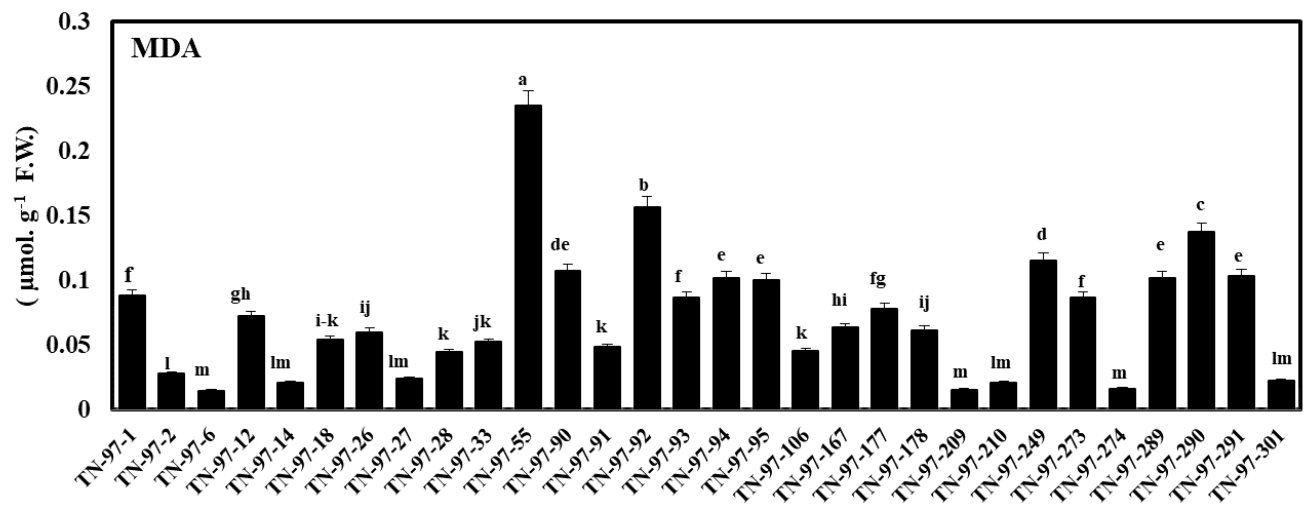

Cultivars

Fig 2. Changes of MDA content in leaf of different flaxseed varieties grown for 30 days under cold stress with $13 \mathrm{~h} /$ day at $11{ }^{\circ} \mathrm{C}$ and 11 $\mathrm{h} /$ night at $8^{\circ} \mathrm{C}$.

Table 3. Mean squares (MS), percent coefficient of variation (CV) from analysis of variance for various traits of Linum varieties grown for 30 days under cold stress with $13 \mathrm{~h} /$ day at $11^{\circ} \mathrm{C}$ and $11 \mathrm{~h} /$ night at $8{ }^{\circ} \mathrm{C}$.

\begin{tabular}{|c|c|c|c|c|c|c|c|c|c|c|}
\hline Source & DF & Chl a & Chl b & $\mathrm{T}$ chl & Car & MDA & POX & CAT & Betaine & Proline \\
\hline Variety & 29 & $18.94 * *$ & $42.23 * *$ & 117.08 ** & $1.84 * *$ & 0.007 ** & 0.0008 ** & $0.102 * *$ & $0.43 * *$ & 0.29 ** \\
\hline Error & 60 & 0.071 & 0.118 & 0.265 & 0.005 & 0.00 & 0.00 & 0.004 & 0.008 & 0.031 \\
\hline $\mathrm{CV} \%$ & & 5.61 & 5.43 & 4.65 & 6.13 & 8.07 & 22.35 & 8.11 & 18.43 & 9.81 \\
\hline
\end{tabular}

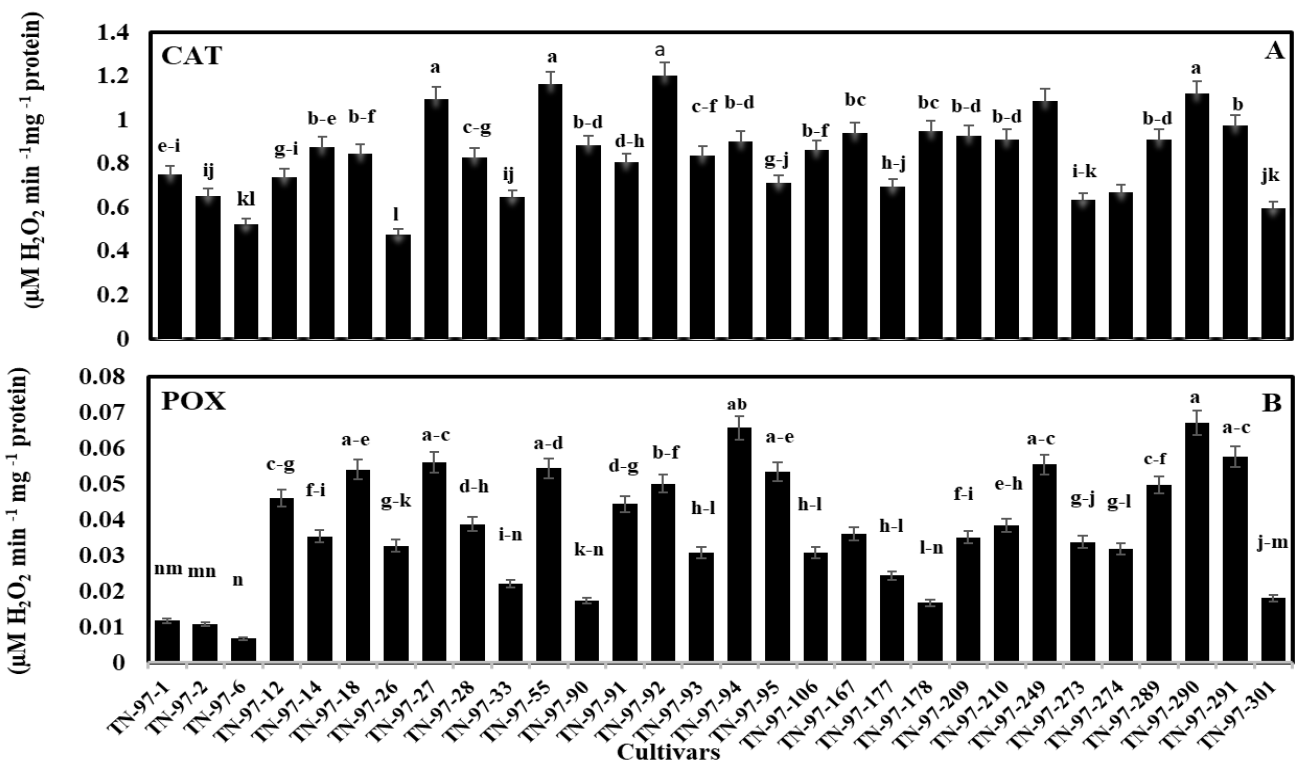

Fig 3. Changes of CAT (A) and POX (B) content in leaf of different flaxseed varieties grown for 30 days under cold stress with 13 h/day at $11{ }^{\circ} \mathrm{C}$ and $11 \mathrm{~h} /$ night at $8{ }^{\circ} \mathrm{C}$. 
Table 4. Eigen value, factor scores and contribution of the first nine principal component variations among Linum usitatissimum varieties.

\begin{tabular}{lllll}
\hline Variable & PC1 & PC2 & PC3 & PC4 \\
\hline Chlorophyll a & -0.384 & 0.304 & -0.018 & -0.092 \\
Chlorophyll b & -0.384 & 0.304 & 0.019 & -0.088 \\
Total chlorophyll & -0.384 & 0.306 & 0.005 & -0.086 \\
Carotenoid & -0.390 & 0.276 & 0.001 & -0.088 \\
MDA & -0.263 & -0.281 & -0.896 & 0.068 \\
CAT & -0.266 & -0.432 & 0.187 & 0.269 \\
POX & -0.357 & -0.130 & 0.286 & 0.682 \\
Proline & -0.276 & -0.425 & 0.038 & -0.135 \\
Betaine & -0.249 & -0.426 & 0.280 & -0.638 \\
Eigen value & 5.275 & 2.278 & 0.552 & 0.356 \\
Percentage & 58.600 & 25.300 & 6.100 & 4.000 \\
Cumulative & 58.600 & 83.900 & 90.000 & 94.000 \\
\hline
\end{tabular}
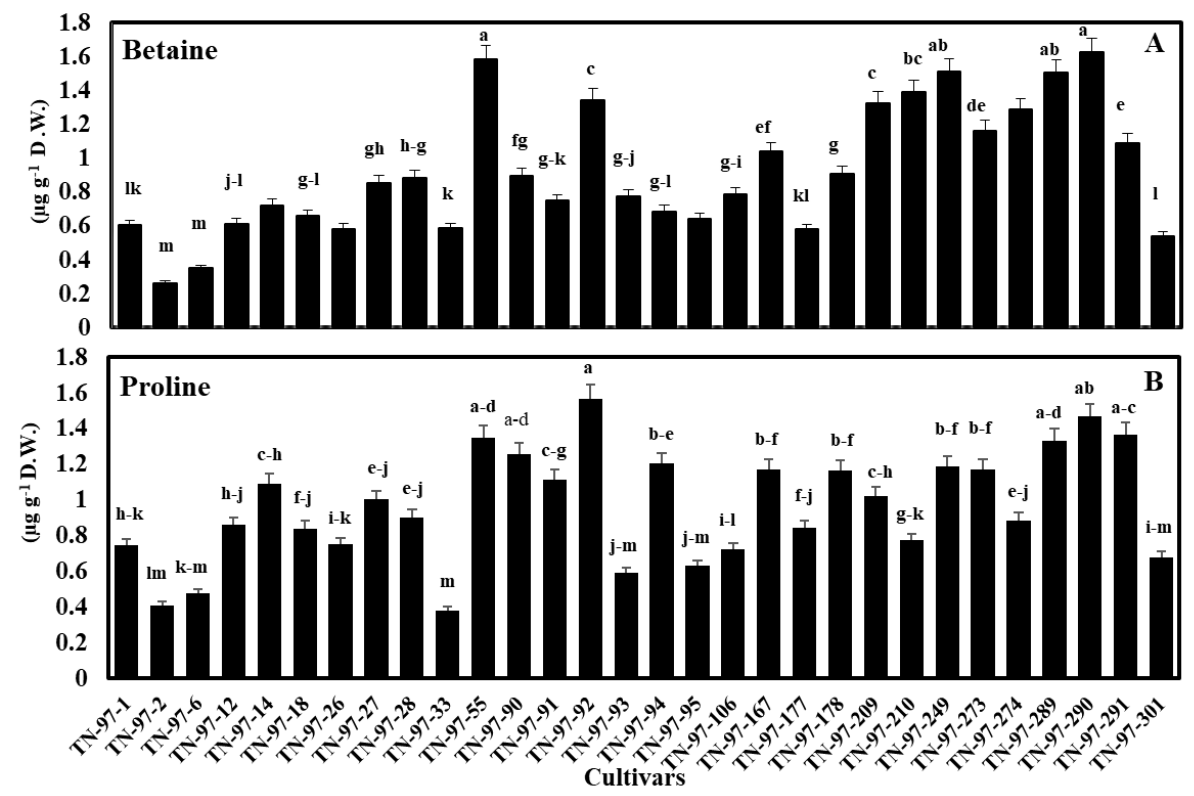

Fig 4. Betaine (A) and proline (B) contents in leaf of different flaxseed varieties grown for 30 days under cold stress with $13 \mathrm{~h} /$ day at $11^{\circ} \mathrm{C}$ and $11 \mathrm{~h} /$ night at $8{ }^{\circ} \mathrm{C}$.

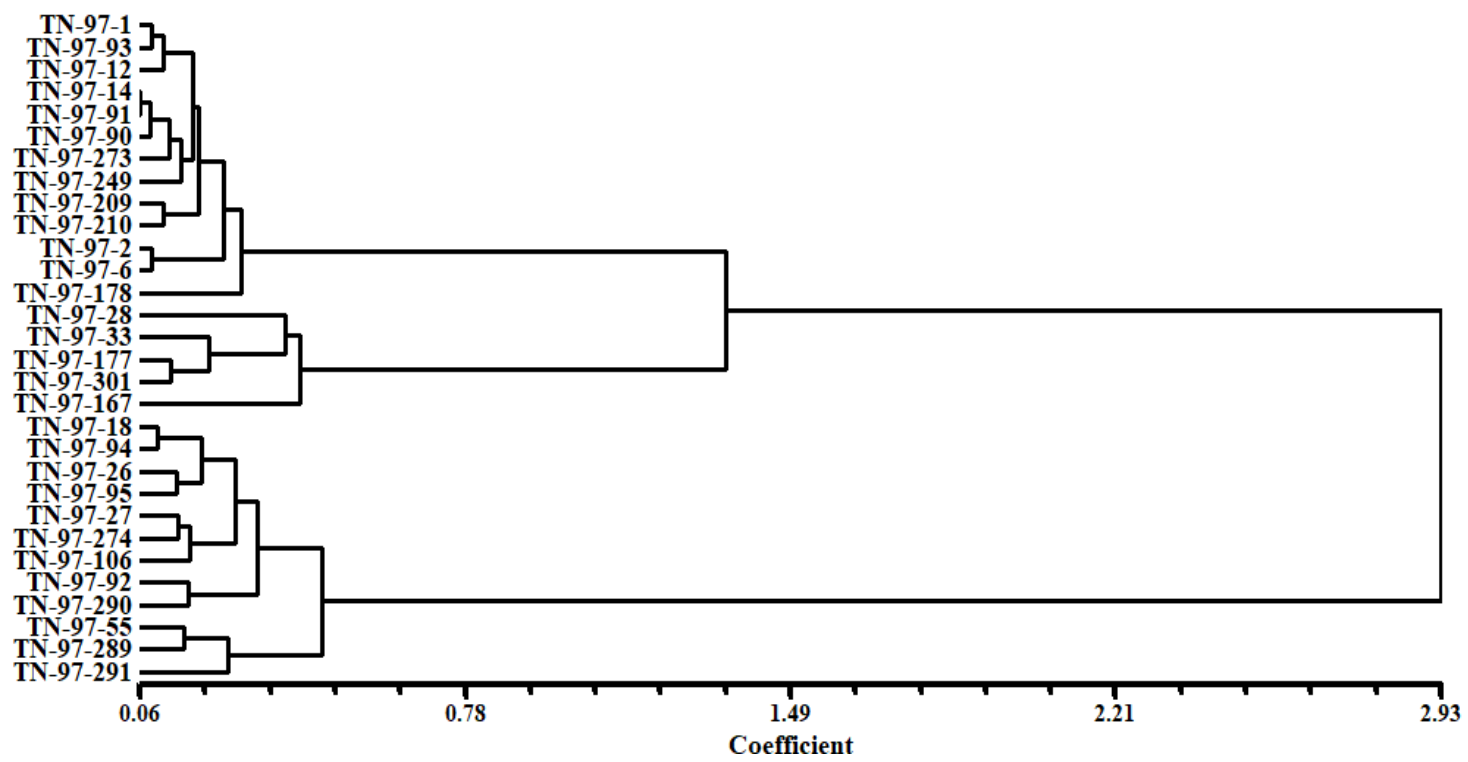

Fig 5. Dendrogram depicting relationships among 30 Linum usititassimum varieties based on physiological data using UPGMA clustering. 


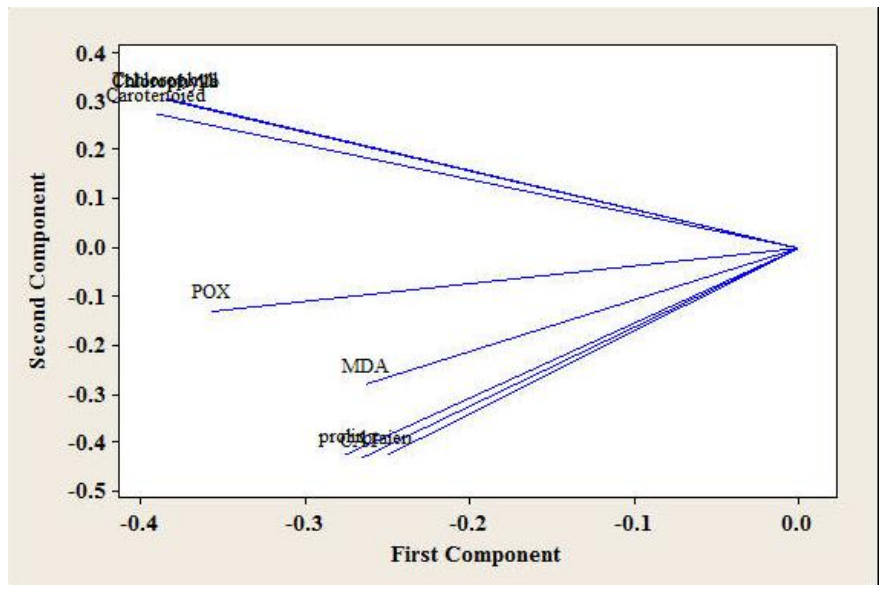

Fig 6. Loading plot of physiological traits.

Chlorophyll is an extremely important and critical biomolecule in photosynthesis with function of light absorbance and light energy transformation (Liu et al., 2013). MDA is one of the membrane fat peroxidation products when plant organs are undergoing adverse conditions or aging conditions (Tabassum et al., 2014). Increase in MDA level means the membranous peroxidation action is introduced and anti-reversion force will be strengthened. Increment in the lipid peroxidation was reported under cold stress. Lower MDA content means higher antioxidative ability, reflecting higher cold resistance (Fahimirad et al., 2013). In our experiment, flaxseed varieties responded differently to cold stress and TN-97-301 and TN-976 showed the highest MDA content signifying sever membrane phospholipids peroxidation and low cold tolerance, while the minimum content was observed in TN-97-92 and TN-97-55 varieties, revealing their high cold resistance ability. Cold stress induces the accumulation of ROS such as superoxide, hydrogen peroxide, and hydroxyl radicals (Mittler et al., 2002 and Suzuki et al., 2006). The elevated concentration of ROS can damage cellular structures and macro molecules, leading to cell death (Krasensky et al., 2012). Plants under abiotic stress have evolved a defense system against oxidative stress by increasing the activity of ROS-scavenging enzymes. The CAT is an important protective enzyme in the plant tissue which plays an important role in the removal of $\mathrm{H}_{2} \mathrm{O}_{2}$ level (Mittler et al., 2002). Under our chilling experiment, higher CAT activity was detected in TN-97-55, TN-97-92 and TN-97-290 varieties indicating their higher cold tolerance and TN-97-6, TN-97-7 and TN-97-301 varieties showing the lowest activity of CAT were classified as cold sensitive ones. ROS can also be scavenged by POX. POX is a member of oxidoreductases and catalyzes the oxidation of a wide variety of organic and inorganic substances such as nitrite in the presence of hydrogen peroxide (Goud and Kachole 2012). POX enzymatic activity was at highest in TN-97-94 and TN-97-varieties grouping these varieties as tolerant varieties while TN-97-2, TN-97-3 and TN97-301 varieties, with the lowest activity, were identified as sensitive ones (Fig. 5). The exogenous application of betaine can protect higher plants against low temperature stress. Betaine is thought to play adaptive roles in inducing osmotic adjustment and protecting subcellular structures in stressed plants (Ashraf \& Foolad 2007). Among 30 flaxseed varieties studied, the TN-97-92, TN-97-290, TN-97-291 and TN-97-55 appeared with highest content revealing their higher tolerance capacity (Fig. 3). However, varieties including TN-97-12, TN97-178, TN-97-301, TN-97-14, TN-97-1, TN-97-2, TN-97-6 were grouped as the lowest accumulators of betaine and nontolerant varieties. Many plants accumulate free proline in response to low temperature (Liu et al., 2003). Proline content is increased in potato hybrids when plants are subjected to cold treatment (Koç et al., 2010). The proline acts as osmolytes to facilitate osmoregulation, protecting plants from dehydration due to cold stress which reduces water potential of plant cells (Sz'ekely et al., 2008; Liu et al., 2009). Proline can balance the cellular metabolism, thus the anti-reversion force of plants will be enhanced (Ashraf et al., 2011; He et al., 2016). Based on our analysis TN-97-55, TN-97-92, TN-97-290 and TN-97-291 contained the highest proline level and classified as tolerant varieties while the lowest proline accumulators, including TN97-301, TN-97-5, TN-97-2, and TN-97-6 were clustered as non-tolerant varieties. PCA is the most multivariate method used for classification of samples with diverse biological status, origin or quality ( Low et al., 2012; Kim et al., 2013). The combination of hierarchical clustering analysis and PCA could classify thirty flaxseed varieties into three major groups using various physiological parameters to discriminate their level of cold tolerance (Figs. 5 and 6). Clusters I and II demonstrated lower cold scores, including CAT, POX, betaine, proline than those placed in cluster III, indicating the cold sensitive groups. However, flaxseed plants placed in cluster III comprised of varieties that showed higher cold scores indicating their more tolerance to cold. Correlation coefficient of similarity matrix and dendrogram was calculated (0.94) which shows good relationship between the result of similarity matrix and cluster analysis. Of all thirty flaxseed varieties evaluated, TN-97-55, TN-97-92, TN-97-290 and TN-97-291 were considered the most tolerant varieties.

\section{Materials and Methods}

\section{Plant materials}

Seeds of thirty flax varieties were obtained from Agriculture Research Center of Urmia, West Azerbijan, Iran. All seeds were 
sterilized in $75 \%$ ethanol $(\mathrm{v} / \mathrm{v})$ and then germinated on filter paper moistened with distilled water at $8 / 11^{\circ} \mathrm{C}$ in the dark for 5 days. The uniformly germinated seeds were planted in pots filled with a transplanting medium containing peat moss, vermiculite and perlite $(10: 1: 1, \mathrm{v}: \mathrm{v}$ : v). Each pot contained 4 plants and considered as one replicate and experiment was performed in three replicates. For the cold stress treatment, the plants were grown in growth chamber for 30 days with $13 \mathrm{~h} /$ day at $11{ }^{\circ} \mathrm{C}$ and $11 \mathrm{~h} /$ night at $8{ }^{\circ} \mathrm{C}$. The leaf and root tissues were harvested after treatment and frozen in liquid nitrogen.

\section{Pigments, MDA, betaine and proline contents measurement}

Chlorophyll a, chlorophyll b and carotenoid contents were determined based on the method of Yaryura et al., (2009). MDA level was estimated according to the corrected TBA method (Hodges et al., 1999). For determination of betaine, procedure of Grieve and Grattan (1983) was followed. The proline was determined using method described by Bates et al., (1973).

\section{Antioxidant enzymes activity measurement}

For antioxidant enzyme assays, frozen leaves were ground to a fine powder with liquid nitrogen and were extracted with icecold 0.1 M Tris- $\mathrm{HCl}$ buffer $(\mathrm{pH} 7.5)$ containing $5 \%(\mathrm{w} / \mathrm{v})$ sucrose and $0.1 \% \beta$-mercaptoethanol (3:1 buffer volume/FW). The homogenate was centrifuged at $10000 \mathrm{~g}$ for $20 \mathrm{~min}$, at $4{ }^{\circ} \mathrm{C}$, and the supernatant was used for enzyme activity and protein determinations. Preparation of extract and enzymatic assays were carried out at $4^{\circ} \mathrm{C}$. CAT activity was determined by monitoring the disappearance of $\mathrm{H}_{2} \mathrm{O}_{2}$ at $240 \mathrm{~nm}\left(\varepsilon=40 \mathrm{mM}^{-1}\right.$ $\mathrm{cm}^{-1}$ ) according to the method of Aebi (1984). Total POX activity was assayed as described by Malik and Singh (1980).

\section{Data processing and analysis}

The experiment was conducted with three replications. Analysis of variance was performed by one-way ANOVA using SPSS software (version 23, SPSS, Chicago, IL). Similarity was estimated according to MANHAT dissimilarity index and dendrogram constructed based on UPGMA method using the numerical taxonomy multivariate analysis system software package (NTSYS-pc), version 2.02 (Rohlf, 2002). The representativeness of the dendrogram was evaluated by estimating cophenetic correlation coefficient for the dendrogram and comparing it with the dissimilarities matrix using Mantel matrix correspondence test. The PCA analysis was carried out using Minitab 17.0 software.

\section{Conclusion}

Based on multiple physiological indexes, TN-97-55, TN-97-92, TN-97-290 and TN-97-291 are identified as tolerant varieties and recommended for cultivation in clod areas. This could provide a reference for further research and variety evaluation in breeding and commercial production of flaxseed.

\section{Acknowledgments}

The authors give special thanks to authorities of Institute of Biotechnology of Urmia University for providing facilities.

\section{References}

Aebi H (1984) Catalase in vitro. Methods Enzymol. 105:121126.

Aghaee A, Moradi F, Zare-Maivan H, Zarinkamar F, Pour Irandoost H, Sharifi P (2011) Physiological responses of two rice (Oryza sativa L.) genotypes to chilling stress at seedling stage. Afr J Biotechnol. 10(39):7617-7621.

Alexey AD, Anna VK, George SK, Nadezhda VK, Anna SS, Anastasia AK, Maxim SB, Anastasia VS, Asiya FS, Nataliya VK, Tatiana AR, Olga YY, Olg VM, Nadezhda LB, Nataliya VM (2016) Gene expression profiling of flax (Linum usitatissimum L.) under edaphic stress. BMC Plant Biol. 16(3):139-146.

Ashraf M, Foolad MR (2007) Roles of glycinebetaine and proline in improving plant abiotic stress resistance. Environ Exp Bot. 59: 206-216.

Ashraf MA, Maah, MJ, Yusoff I (2011) Study of tin accumulation strategy by Cyperus species in pot experiments. Res J Chem Environ. 15 (1): 88-98.

Bates LS, Waldren RP, Teare ID (1973) Rapid determination of free proline for water-stress studies. Plant Soil. 39: 205.

Braam J (2005) In touch: plant responses to mechanical stimuli. New Phytol. 165: 373-389.

Fahimirad S, Karimzadeh G and Ghanati F (2013) Coldinduced changes of antioxidant enzymes activity and lipid peroxidation in two canola (Brassica napus L.) varieties. JPPB. 3(1): 1-11.

Farooq M, Aziz T, Wahid A, Lee DJ (2009) Chilling tolerance in maize: agronomic and physiological approaches. Crop Pasture Sci. 60: 501-516.

Goud PB, Kachole MS (2012) Antioxidant enzyme changes in neem, pigeonpe and mulberry leaves in two stages of maturity. Plant Signal Behav. 7: 1258-1262.

Grieve CM, Grattan SR (1983) Rapid assay for determination of water soluble quaternary ammonium compounds. Plant Soil. 70: 303.

Habibi G (2012) Exogenous salicylic acid alleviates oxidative damage of barley plants under drought stress. Acta Biol Szeged. 56(1): 57-63.

He SH, Zhao K, Lingfa M, Jingjun Y, Yuwei CH, Ashraf MA (2016) Comparison of cold resistance physiological and biochemical features of four Herba Rhodiola seedlings under low temperature. Saudi J Biol Sci. 23(2): 198-204.

Hodges D, DeLong J, Forney C, Prange R (1999) Improving the thiobarbituric acid-reactive-substances assay for estimating lipid peroxidation in plant tissues containing anthocyanin and other interfering compounds. Planta. 207: 604.

Kim JK, Park SY, Lim SH, Yeo Y, Cho HS, Ha SH (2013) Comparative metabolic profiling of pigmented rice (Oryza sativa L.) cultivars reveals primary metabolites are correlated with secondary metabolites. J Cereal Sci. 57 :14-20.

Koç E, İşlek C and Ustün AS (2010) Effect of cold on protein, proline, phenolic compounds and chlorophyll content of two pepper (Capsicum annuum L.) varieties. G U J Sci. 23(1): 1-6.

Krasensky J, Jonak C (2012) Drought, salt, and temperature stress-induced metabolic rearrangements and regulatory networks. J Exp Bot. 63(4):1593-1608.

Liu H, Zhu ZJ, Lu GH, Qian QQ (2003) Study on relationship between physiological changes and chilling tolerance in grafted watermelon seedlings under low temperature stress. 
Sci Agric Sinica. 36(11): 1325-1329.

Liu A, Tegmark M, Bowman J, Hewitt J, Zaldarriaga M (2009) An improved method for $21-\mathrm{cm}$ foreground removal. Mon Not R Astron Soc. 398(1): 401- 406.

Liu W, Yu K, He T, Li F, Zhang D, Liu J (2013) The low temperature induced physiological responses of Avena nuda L., a cold-tolerant plant species. Sci World J. 2013, 1-7.

Low M, Deckmyn G., Op de Beeck M, Blumenrother M.C, Osswald W, Alexou M, Jehnes S, Haberer K, Rennenberg H, Herbinger K, Haberle KH, Bahnweg G, Hanke D, Wieser G, Ceulemans R, Matyssek R, Tausz M (2012) Multivariate analysis of physiological parameters reveals a consistent $\mathrm{O} 3$ response pattern in leaves of adult European beech (Fagus sylvatica)New Phytol., 196: 162-172.

Malik CP, Singh MB (1980) Plant enzymology and histoenzymology: a text manual. In: Malik CP and Singh MB (eds), 4th edn. Kalyani Publishers, New Delhi.

Matteucci M, D’Angeli S, Errico S, Lamanna R, Perrotta G, Altamura MM (2011) Cold affects the transcription of fatty acid desaturases and oil quality in the fruit of Olea europaea L. genotypes with different cold hardiness. J Exp Bot. 62:3403-3420.

Mittler R (2002) Oxidative stress, antioxidants and stress tolerance. Trends Plant Sci. 7(9): 405-410.

Tabassum N, Rafique U, Balkhair Kh, Ashraf MA (2014) Chemodynamics of methyl parathion and ethyl parathion: adsorption models for sustainable agriculture. Bio Med Res Int. 1-8.

Patel D, Franklin K A (2009) Temperature-regulation of plant architecture. Plant Signal Behav. 4(7): 577-579.

Rohlf FJ (2002) NTSYSpc: Numerical taxonomy system, ver. 2.1. Setauket, Exeter Publishing Ltd. New York.

Ruelland E, Zachowski A (2010) How plants sense temperature. Environ Exp Bot. 69:225-232.

Sanghera GS, Wani SH, Hussain W, Singh NB (2011) Engineering cold stress tolerance in crop plants. Curr Genomics. 12: 30-43.

Seo PJ, Kim MJ, Park JY, Kim SY, Jeon J, Lee YH, Kim J, Park CM (2010) Cold activation of a plasma membranetethered NAC transcription factor induces a pathogen resistance response in Arabidopsis. Plant J. 61: 661-671.
Székely G, Ábrahám E, Cséplő Á, Rigó G, Zsigmond L, Csiszar J, Ayaydin F, Strizhov N, Jasik J, Schmelzer E, Koncz C, Szabados L (2008) Duplicated P5CS genes of Arabidopsis play distinct roles in stress regulation and developmental control of proline biosynthesis. Plant J. 53(1):11-28.

Suzuki N, Mittler R (2006) Reactive oxygen species and temperature stresses: A delicate balance between signaling and destruction. Physiol Plant. 126: 45-51.

Wang GL, Guo ZF (2005) Responses of photorespiration to chilling stress in rice with different chilling tolerance. Acta Agronomica Sinica. 31(5): 673-676.

Yaryura P, Cordon G, Leon M, Kerber N, Pucheu N, Rubio G, Garcia A, Lagorio MG (2009) Effect of phosphorus deficiency on reflectance and chlorophyll fluorescence of cotyledons of oilseed rape (Brassica napus L.). J Agron Crop Sci. 195(3):186-96.

Zhang S, Jiang H, Peng S, Korpelainen H, Li C (2011) Sexrelated differences in morphological, physiological, and ultrastructural responses of Populus cathayana to chilling. J Exp Bot. 62:675-686.

Zhang BQ, Yang LT, Li YR (2015) Physiological and biochemical characteristics related to cold resistance in sugarcane. Sugar Tech. 17(1):49-58. 